\title{
Extra-parliamentarian Political Power and (Social) Media Visibility
}

\author{
Uldam, Julie
}

Document Version

Accepted author manuscript

Published in:

Journal of Political Power

DOI:

10.1080/2158379X.2019.1624058

Publication date:

2019

License

Unspecified

Citation for published version (APA):

Uldam, J. (2019). Extra-parliamentarian Political Power and (Social) Media Visibility. Journal of Political Power, 12(2), 293-311. https://doi.org/10.1080/2158379X.2019.1624058

Link to publication in CBS Research Portal

\section{General rights}

Copyright and moral rights for the publications made accessible in the public portal are retained by the authors and/or other copyright owners and it is a condition of accessing publications that users recognise and abide by the legal requirements associated with these rights.

Take down policy

If you believe that this document breaches copyright please contact us (research.lib@cbs.dk) providing details, and we will remove access to the work immediately and investigate your claim. 


\title{
Extra-parliamentarian Political Power and (Social) Media Visibility
}

\author{
Julie Uldam \\ Journal article (Accepted manuscript*)
}

\section{Please cite this article as:}

Uldam, J. (2019). Extra-parliamentarian Political Power and (Social) Media Visibility. Journal of Political Power, 12(2), 293-311. https://doi.org/10.1080/2158379X.2019.1624058

This is an Accepted Manuscript of an article published by Taylor \& Francis in Journal of Political Power on 11 Jun २०19, available online:

DOI: http://www.tandfonline.com/10.1080/2158379X.2019.1624058

* This version of the article has been accepted for publication and undergone full peer review but has not been through the copyediting, typesetting, pagination and proofreading process, which may lead to differences between this version and the publisher's final version AKA Version of Record.

Uploaded to CBS Research Portal: May २०२० 
Extra-parliamentarian political power and (social) media visibility

Julie Uldam, Department of Management, Society and Communication, Copenhagen Business School, Denmark

Accepted pre-publication version. Please cite as:

Uldam, J. (2019). Extra-parliamentarian political power and (social) media visibility. Journal of Political Power, 12(2), 293-311. 


\section{Extra-parliamentarian political power and (social) media visibility}

This article proposes a typology of extra-parliamentarian politics and access to parliament. On the basis of this, it discusses implications for reliance on (social) media visibility and its implications for (dis)empowerment. Theoretically, the article draws on media studies, social movement studies, political science and social theory, particularly conceptions of the public sphere, political participation and visibility. Empirically, it draws on examples of extra-parliamentarian political actors with little or no access to parliament and policy makers and illustrates the ways in which reliance on social media visibility is influenced by an interplay between access to parliament and degree of anti-systemicism.

Keywords: activism; extra-parliamentarian politics; media; social media; visibility

\section{Introduction}

This article introduces a typology of the interplay between extra-parliamentarian politics and access to parliament. I propose that the typology can help capture media power by pointing to implications for having to rely on social media visibility. Digital media, and especially social media platforms, have been praised for their potential for empowering extra-parliamentarian political actors by providing inexpensive possibilities for visibility (e.g. Castells 2013). However, sceptics have pointed to the embeddedness of social media in wider societal power structures, which privilege corporate and parliamentarian political actors with economic resources (e.g. Fenton 2016). This article examines these potentialities and constraints in relation to different extra-parliamentarian political actors, including NGOs and anti-systemic activists, arguing that reliance on social media visibility is significantly influenced by an interplay between access to parliamentary political actors and degree of antisystemicism. Theoretically, the article draws on media studies, social movement studies, political science and social theory, particularly conceptions and discussions of 
the public sphere, political participation and visibility. Empirically, it draws on examples of extra-parliamentarian political actors with little or no access to parliament and policy makers. The examples centre on the UN Framework Convention on Climate Change conferences (UNFCCC) and are drawn from two research projects that both involved participant observation and interviews with key activists. This article proceeds by first outlining key theoretical debates on political participation before zooming in on discussions on digital media in relation to political participation. On the basis of this, it suggests a typology of the interplay between extra-parliamentarian politics and access to parliament. Next, it introduces the notion of mediated visibility. It then outlines methods and case examples before illustrating the dynamics of the typology and its implications for potential for (dis)empowerment. The article concludes with a discussion of the significance of context.

Before we can begin to assess potentialities and constraints of social media visibility and access to parliamentary political actors, we need to first address fundamental questions about what political participation entails and what role it should have in contemporary societies. This includes questions of power relations.

\section{Theoretical backdrop: extra-parliamentarian political communication}

At the intersection of media studies and social movement studies key discussions of political participation argue for an understanding that captures the efforts of civil society actors to address issues of public concern beyond the rights and obligations of liberal citizenship, such as voting (e.g. Bennett 2003, 2012; Carpentier 2012; Dahlgren 2009; Fenton 2008; Mouffe 2005).

In this way, we can distinguish between, on the one hand, formal participation such as voting and, on the other hand, extra-parliamentarian political participation 
such as volunteering, activism, and participation in community-driven initiatives. Political participation, then, is understood here as engagement with political and social issues, an engagement expressed in a variety of ways that do not always adhere to traditional perceptions of parliamentarian politics. A by now oft cited example is the Occupy movement with its protest camps, which served both to protest against the influence of corporate power on parliamentarian politics (among other issues) and to enact a community-driven alternative to the current neoliberal organization of society, e.g. with free libraries, free seminars, and experiments in direct democracy (e.g. Bailey and Bates 2012). Political participation is also expressed through direct action including street protests and creative interventions such as the 2004 campaign Billionaires for Bush (Cammaerts 2007; Lechaux 2010).

From this inclusive conception of politics as also located beyond parliamentarian arenas and spurred by civic actors follows questions about the public sphere and modes of participation. A significant part of the research on civil society actors' access to the public sphere departs from a long-standing axiom of political theory, underwritten by the Habermasian model of deliberative democracy that debate on matters of public concern between empowered citizens is an essential prerequisite for a vital, functioning democracy (Habermas 1962/1989; see Downey and Fenton 2003; Lunt and Livingstone 2013; Mansell 2010 for useful discussions). Dahlgren (2009) maintains that it is imperative not to lose sight of the classic idea that democracy resides, ultimately, with citizens who deliberate matters of public concern. Yet, while asserting the significance of informed political debates between citizens to the democratic process and the various ways these manifest themselves online, Dahlgren points towards the limits of the model of deliberative democracy for understanding the affective and culturally embedded dimensions of politics and 
citizenship. These shortcomings become especially pronounced when studying noninstitutional politics and the various ways civic actors engage politically online and outside the confinements of the formal representative system (Dahlgren 2009; Couldry 2006). Leaning on Dahlgren's framework then entails acknowledging antagonisms and the messiness of the everyday as part of being political. This raises important questions about what counts as political and what counts as legitimate political communication.

In this vein, scholars have pointed to the limits of the model of deliberative democracy for understanding the affective and conflictual dimensions of extraparliamentarian politics, highlighting the role of consensus and rationality in obscuring power relations and privileging political participation based on individualization and consumption in the market-place over solidarity and proposals for alternative solutions (Dahlgren 2009; Fenton 2007).

In order to capture antagonistic and conflictual aspects of extraparliamentarian political participation, a distinction between informal and formal modes is useful (Böhm et al., 2008). Here, formal modes of political participation are taken to refer to acts of contestation in institutional contexts such as trade union strikes, or NGO involvement in policy processes (Blach-Ørsten and Kristensen 2016; Böhm et al., 2008). In this way, informal modes of political participation also resemble the corporatist structure in its traditional sense through the integration of e.g. employers' associations, trade unions, and other interest groups in the policy making process (Binderkrantz et al. 2015; Ørsten and Kristensen 2016).

In contrast, informal modes of extra-parliamentarian political participation are taken to refer to political participation 'outside official politics', including 'spontaneous non-organized actions to collectively organized protest events' by non- 
professionals such as culture jamming and direct action' (Böhm et al. 2008; Lilja et al. 2017). These informal modes of resistance are characterized by decentralized, nonhierarchical (or anti-hierarchical at least) organizing (Böhm et al. 2008; Den Hond and De Bakker 2007; Lilja and Vinthagen 2018). This distinction is not unproblematic as the two forms of resistance often overlap (see Ahrne et al. 2016 and Schoeneborn and Scherer 2012 for insightful discussions in terms of partial organization). It is nonetheless useful for understanding political participation, because it allows us to explore the ways in which extra-parliamentarian politics and political participation are multifarious, including participation in relation to issues such as global justice, anticapitalism, climate change, and gender equality. For political expression to be imbued with agency it needs to be seen and heard by others in the space of appearance (Arendt 1958). Here, this article draws on Dahlgren's $(2005,2009)$ critique of deliberative democracy. In his critique, Dahlgren (2005) takes his point of departure in online media and points to the relevance Fraser's notion of subaltern counterpublics as a way to theorise the mushrooming of online spaces for the expression and proliferation of extra-parliamentarian politics. Dahlgren cautions celebratory views of these spaces as vehicles for a reinvigorated public sphere, as possibilities for accessing the dominant public sphere remain crucial. Despite the possibilities for cheap, horisontal communication afforded by many online media platforms, a lot of the information that we receive online presents one aspect of an issue, and many spaces co-exist as echo chambers without ever overlapping, merely connecting likeminded users rather than challenging presumptions (Dahlgren 2005). In this view, extra-parliamentarian political actors, including social movements and interest organisations, risk only achieving visibility in counter-publics isolated from other counter-publics and the mainstream public sphere (Dahlgren 2001). Extra- 
parliamentarian political actors can wage significant influence on policy processes outside the public sphere(s) (Binderkrantz 2005). These possibilities and the policy machinery in which they are embedded have been usefully illuminated in political science (e.g. Beyers et al. 2008; Binderkrantz 2008; Christiansen et al. 2004). This article follows Dahlgren $(2005,2009)$ in focusing on extra-parliamentarian political actors' communicative efforts to access the public sphere(s), and particularly the role of social media.

The different notions of citizenship and political participation outlined above deliberative, agonistic, formal/informal resistance - are all underpinned by notions of power. Focusing on communicative aspects of extra-parliamentarian politics, this article approaches citizenship and political participation from the perspective of discursive power (Laclau and Mouffe 1985). Building on a Gramscian concept of hegemony, Laclau and Mouffe conceptualise power in terms of the capacity of discourse to condition our understandings of the world and, ultimately, our possibilities to act in that world (Laclau and Mouffe 1985). The idea here is not to privilege agency over structure. Rather, it is a position between voluntarism and structuralism where discourses work as partial limitations that structure conditions of possibility through the construction of 'common sense' in a particular space or sphere of the social, or in society more broadly (Author 2010; Böhm et al. 2005; Griggs and Howarth 2004). For example, the promotion of individual oriented initiatives such as political consumption as a solution to climate and humanitarian crises can be seen as underpinned by the dominance of assumptions of a market-based organization of society (Boltanski and Chiapello 2006; Richey and Ponte 2011). These issues lie at the heart of Mouffe's (2005: 50-56) argument with Giddens' (1991) notion of life politics and Beck's (1994) notion of subpolitics. Mouffe (2005: 50) argues that the grounding of these notions in 
individualism removes them from conceptualisations of collective power, which are essential to any counter-hegemonic project. Against this backdrop, this article departs from a dichotomous approach to domination and empowerment, 'power over' and ‘power to’ (Allen 1998; Bloom 2013; Haugaard 2012, 2015). In doing so, it adopts an integrative approach that aims to capture inclusions and exclusions in relation to antisystemic/reformist extra-parliamentarian political actors' access to parliamentary politics, the role of media companies and their business models in granting visibility and access to the public sphere and the disciplinary power of visibility. It connects this to Haugaard's (2003) typology of power. This helps capturing the ways in which power created from an interplay between social order, system bias, systems of thought, tacit knowledge, reification, discipline and coercion in the dynamics at play when social media platforms become vehicles for visibility in the public sphere(s) and the dual capacity of visibility to empower and disempower.

\section{Digital media - Empowering extra-parliamentarian politics?}

Historically, new media technologies have been greeted as ground-breaking tools for a revitalisation of the public sphere, social media being no exception (Calhoun 2002: 147). Optimistic perspectives on the advantages of the internet - and more recently social media - as a public sphere focuses on opportunities for affording greater participation and possibilities for resistance, action and organisation by opening new terrains for struggles for visibility for groups excluded from the mainstream media (e.g. Kahn and Kellner 2004; Carroll and Hackett 2006; Bennett 2003; Papacharissi 2002).

Building on critiques of the Habermasian conception of the public sphere (Dahlgren 1995; Calhoun 1992; Fraser 1992), Fenton and Downey (2003) have suggested a distinction between dominant and counter public spheres to capture the 
difference between, on the one hand, 'dominant media' and, on the other hand, 'civic media', along with the time and space made available for civil society actors by dominant media (18-19). It is in counter public spheres that extra-parliamentarian political actors can connect and organize for social change. Following the distinction between dominant and counter public spheres, the mushrooming of social media can be seen as a vehicle for counter public spheres that can challenge the dominant public sphere and its reliance on traditional mainstream media. But with the commercialization of popular social media platforms such as Facebook and YouTube, a distinction between a dominant public sphere fostered by traditional mainstream media and counter public spheres fostered by social media would be problematic. At the same time, a lot of the information that we receive via social media platforms presents one aspect of an issue, bits of information or factoids, connecting likeminded users (within specific alternative public spheres) rather than challenging our presumptions or offering new perspectives. Therefore, I suggest that we can distinguish between a dominant public sphere that relies on traditional mainstream media and, following Gitlin (1998), multiple public sphericules that variously rely on mainstream, commercial social media and alternative social media. In doing so, I want to stress the importance of interaction between public sphericules and between public sphericules and the dominant public sphere (see Cammaerts 2007).

Social media have been celebrated for their potential to provide civil society actors with the opportunity to access the dominant public sphere. However, we need to consider what kinds of extra-parliamentarian political communication is played out in different social media platforms and the public sphere(s) they facilitate. Bennett et al. (2014) identify loosely networked activism that addresses issues that reflect personal values in social media that transcends institutional or communal affinities. In this way, 
they share the idea that social media enable engagement with politics in ways that are self-actualizing rather than dutiful, in Bennett's terms, thus contributing to a vivid civic culture that is understood in much broader terms than suggested by Almond and Verba (1963) in their seminal study of civic culture and politics (Bennett et al. 2011; Bennett et al. 2014). While social media thus provide new platforms for expressing and acting out civic engagement beyond politically oriented fora, they have also been shown to privilege formal (reformist and institutional) modes of civic engagement over informal (radical and anti-systemic) modes (Author 2013; Van Laer and Van Aelst 2010) and individual over collective engagement (Bennett and Segerberg 2013; Fenton and Barassi 2011). Therefore, when we explore the potential of social media for reinvigorating extra-parliamentarian politics, we need to consider (i) both the role of reformist and anti-systemic agendas, and (ii) their (possibilities for providing) access to (the) public sphere(s). I will return to this in the typology I suggest below. First, I turn to the empowering and disempowering potentialities of visibility to extraparliamentarian political actors.

\section{The paradox of visibility}

Thompson's (2005) notion of mediated visibility can help capture the ambiguous capacity for visibility that social media platforms afford extra-parliamentarian political actors. In pointing to the role of the media as key to the relation between visibility and power, Thompson (2005) departs from Foucault's notion of the panopticon and the idea that the visibility of the many works as a means of control. Instead he argues that in our media saturated society political actors are increasingly visible to wider publics, and that this entails both reputational opportunities and challenges. On the one hand, the media grant visibility to (media-savvy) political actors independent of spatial-temporal 
locales. On the other hand, the conducts of politicians are made visible in uncontrollable ways by the media. This development is augmented and made more complex by the proliferation and popularisation of social media platforms as they simultaneously provide new possibilities for self-expression and render parliamentarian political actors increasingly vulnerable to the scrutiny of civil society actors (Thompson 2005). However, social media not only make visible parliamentarian political actors. They also grant visibility to extra-parliamentarian political actors. This entails potential for both empowerment and disempowerment. Their empowering potential relates to their widespread use, ease of access (in some countries), no-fee access, and possibilities for bypassing mass-media filters, which provides non-elite actors with new possibilities for making themselves and their causes visible to wider publics - a condition for and payoff of democratic participation (Dahlgren 2013). Their disempowering risks relate to the interrelations of visibility and control. The visibility afforded by social media operates asymmetrically, enabling governments and corporations to monitor citizens' activities without being seen themselves (Fuchs et al. 2013). In this way, social media augment visibility asymmetries by rendering them less transparent and accountable (Brighenti 2010). The exposure of misconduct by extra-parliamentarian political actors relies on their possibilities for visibility. The popular appeal of social media has made them key platforms for extra-parliamentarian political actors - including social movement and interest organisations' - mobilisation and reporting (Author 2011; Neumayer et al. 2016). At the same time, this visibility enables public authorities to monitor and collect information about the activities of extra-parliamentarian political actors (Author 2014; Dencik et al. 2016; Trottier and Fuchs 2014). Consequently, social media are also key platforms for surveillance, augmenting mutual surveillance practices, e.g. with authorities tracking social movements' activities in social media platforms (Hintz 
2016). In liberal democracies, this monitoring is typically conducted with reference to pre-emptive security measures (Dencik et al. 2016; Hintz, 2016). In regions of political turmoil, imprisonment and torture can be consequences of social media activity (Albu forthcoming 2019). In this way, visibility and surveillance are increasingly interlinked in social media contexts. In this respect, Foucault's notion of disciplinary power through the visibility of the many still bears relevance to the dynamics of visibility visa-vis online media, because it can help capture authorities' practices of monitoring critical voices in digital media platforms and the responses they generate. The revelation of practices of surveillance and open source intelligence has contributed to a shift towards more sceptical perspectives on social media and activism (Author, forthcoming 2020; Dencik et al. 2016). This is closely related to the ways in which the business models that underpin the affordances of popular social media platforms privilege reformist and individual modes over anti-systemic and collective engagement mentioned above (Fenton 2016; Landwehr et al. 2019). The typology that I suggest below can help illustrate the ways in which these dynamics of visibility and social media business models are played out in relation to different types of extraparliamentarian political actors.

\section{A typology of extra-parliamentarian political communication}

To develop a better understanding of the modes and possibilities of extraparliamentarian politics, I suggest a typology that encourages questions about power relations and visibility. The typology I suggest here considers reformist/anti-systemic agendas and tactics in relation to access to parliamentarian political actors. Other typologies have considered aspects such as radical/reformative orientation and tactics to influence corporate social change activities (Den Hond and De Bakker 2007) and 
tactics in relation to internet reliance and degree of risk associated with the tactic (van Lear and van Aelst 2010). More recently, De Bakker (2015) has combined these into a typology of tactics and objectives towards institutional change. Kavada (2013) has proposed a typology of communication strategies, organizing and internet uses and Neumayer and Svensson (2016) have considered the degree of antagonism/agonism in relation to tactics. In different ways, these all function as useful heuristic tools for analyzing dynamics of political agendas, tactics and reliance on digital technologies. The typology that I suggest here contributes to these by explicating the implications of (no) access to parliament and political agendas for the role of visibility and power. Rather than adopting a dualistic perspective, the typology I suggest takes its point of departure in a spectrum of extra-parliamentarian political actors, ranging from reformist to radical actors. At the reformist end of the spectrum we find actors - often formal organisations - who work within existing structures of governance, e.g. by lobbying governments and policy-makers through administrative or parliamentary strategies (Binderkrantz 2008). These organisations are often the focal point of the literature on interest organisations and include business groups, trade unions and associations of public sector institutions with corporative resources (Binderkrantz 2008). Towards the radical end of the spectrum we find groups - often relatively informally organised campaigning for systemic change (Author 2013). Here, government and policy makers are not seen as targets to be influenced through lobbying or campaigning, because they are seen as illegitimate players that represent a corrupt system. Instead, in this view, the system should be revolutionised rather than influenced. Taking climate change as a thematic example, extra-parliamentarian political actors protesting at this end of the spectrum see governmental events such as the UN climate conferences as illegitimate enemies that propose false and profit-driven solutions. As a consequence, typical 
repertoires for action revolve around disruption and logics of symbolic and/or material damage (Author 2013). Between the two ends of the spectrum, multiple different actors draw on a vast variety of different repertoires for action, including established NGOs such as Oxfam and WWF who target governments, policy-makers and corporations. In addition to lobbying, their repertoires for action include petitions, research and aid, and they sometimes form partnerships with their targets (den Hond and de Bakker 2007). In order to capture the power relations at play in extra-parliamentarian politics, a second axis in this typology is necessary. The second axis should also be seen as a spectrum and captures the possibilities of extra-parliamentarian political actors to access the they are trying to influence or disrupt, either directly or via the media. At one end of the spectrum we thus find actors corporative resources and privileged access to parliament and policy makers, who are invited to participate in policy hearing processes and/or with access and resources to lobby politicians and bureaucrats (Binderkrantz 2008; Lang 2013). At the other end of the spectrum we find extra-parliamentarian political actors with no or significantly limited access to parliament and policy makers. Here, several factors can impede access. One reason is that some actors may not have the contacts or the social capital that could enable them to gain access (Lang 2013). Another reason is that others may prefer to distance themselves from authorities so as to retain an uncompromised ideological position, what has been termed 'ideological outsiders' (Grant 2000; Rommetvedt and Opedal 1995, 284). This is related to the view that government is part of the problem and thus an illegitimate player to be eliminated rather than swayed (Christiansen 1999; Author 2013). A third reason is that many extraparliamentarian actors have limited resources which require a decision between a "lobby focus" and "public outreach"/campaigning focus that is often answered in favour of the former (Lang 2013). A significant implication is that many extra- 
parliamentarian political actors rely on visibility among wider publics rather than access to government and bureaucrats.

[Figure 1 near here]

In this way, actors with significantly limited or no access to government and policy makers are more dependent on the media, both the press and social media. The point here is not that media access is a dependent variable in relation to either axis. The point is about assessing needs for visibility and subsequently the role of the mainstream press and social media.

The possibilities afforded by social media potentially enables extraparliamentarian political actors to bypass mass media gatekeepers and gain visibility in the public domain (Cammaerts 2013). Thus, it potentially enables holding governments to account for their actions (Fenton, 2016). However, this is a reciprocal possibility, as social media platforms and their regulation facilitates both the visibility of critics but also government and corporate monitoring, and sometimes censoring, of dissenting views (Dencik et al. 2016; Pickerill 2006; Author, 2015).

\section{Materials and methods}

In the following, I draw on examples of extra-parliamentarian political actors with little or no access to parliament and policy makers in order to illustrate the interrelations between the degree of a reformist-revolutionary agenda, on the one hand, and the level of access to parliament and policy makers on the other in relation to social media visibility. The examples centre on the UN Framework Convention on Climate Change conferences (UNFCCC) as an opportunity structure for bringing attention to the 
detrimental consequences of climate change and suggesting solutions. The examples are drawn from two research projects that both involved participant observation and interviews with activists. One focused on COP17 and protest activities by Londonbased climate activist groups. Participant observation was conducted for four months and involved attending meetings and planning and participating in actions organized in London as well as interviews with thirteen key activist organizers and participants (see also author 2013). This article focuses on the Campaign against Climate Change. The Campaign against Climate Change is a London-based organization that is reformist in its approach, protesting against climate change within the current structures of governance. As such, it was founded as a reaction to the Bush administration's rejection of the Kyoto treaty in 2001, and part of its mission is to "influence those with the greatest power to take effective action to do so with the utmost speed and resolution" (Campaign against Climate Change, nd1). The other project focused on COP15 and protest activities by transnational climate activist groups. Participant observation was conducted for two weeks during COP15 and involved participating in actions organized in Copenhagen. It also involved interviews with climate justice activists undertaken by the author and a colleague (Author 2011, 2014). This article focuses on the Never Trust a COP network. Never Trust a COP was an international group formed to mobilize the radical left across Europe, prior to the COP15 meeting in Copenhagen in 2009. Never Trust a COP was formed as a response to reformist approaches proposed at organizing meetings prior to COP15.

\section{Extra-parliamentarian politics: The UNFCCC as a point of struggle}

\footnotetext{
${ }^{1} \mathrm{http}: / /$ www.campaigncc.org/missionstatement
} 
The UN Climate Conferences held annually since 1995 provide a pertinent focal point, because they function both as a site of political contestation and as a site of media attention, and they bring together a wide range of parliamentarian and extraparliamentarian political actors. In this way, the UN Climate Conferences can aptly help illustrate different positions on the two axes suggested here.

\section{The axis of access}

In relation to the question of access to parliament and policy makers, the UN Climate Conferences operate as sites of carefully orchestrated inclusions and exclusions (Banerjee 2012). They do so by granting (and denying) approvals to attend the conference, classifying participants as "delegates" or "observers", with access to the numerous "closed sessions" that are part of the conferences (Banerjee 2012). Some negotiations are formal sessions, which are usually open to accredited observers, others are organized as informal sessions, which are either open or closed, or as unofficial, behind the scenes meetings (Banerjee 2012). In practice, it is the two latter formats that function as arenas for actual negotiation between representatives of states, industry groups, BINGOs, and inter-governmental organizations (Banerjee 2012). Most attending NGOs are relegated to the exhibits and stalls areas, which are typically physically separated from the main conference area (Banerjee 2012). Some NGOs and activists are not granted accreditation (Holz 2012). In this way, they are excluded from being heard in a particular public sphere. This reflects a system bias that privileges reformist agendas and formal organisations that accept the current system (Cammaerts 2018; Haugaard 2003; Lukes 2005). Other NGOs and activists choose not to apply for accreditation, because they consider the conferences illegitimate policy events and/or because they lack the financial resources to travel to the conference site. In Haugaard's 
terms, choosing not to apply for accreditation, because the conferences are considered illegitimate events goes beyond system bias. It can be seen as an attempt to point to the inclusions and exclusions of the as appearing legitimate, thus attempting to convert “practical consciousness knowledge into discursive consciousness" (Haugaard 2003: 100). In relation to financial resources, at COP17 in 2011, the Campaign against Climate Change provides an apt example of a reformist extra-parliamentarian actor that had no choice but to remain outside the UN Climate Conference to voice their critique, because they did not have the economic resources to go to Durban for the COP17. This illustrates unequal power relations created by system bias insofar as the policy system takes for granted that participants have the resources to travel to distant events. This takes us to the axis of agendas.

\section{The axis of agendas: reformist climate justice activism}

Instead of travelling to the conference site in Durban for COP17, the Campaign against Climate Change organized a London climate justice march, planned to coincide with the UN climate conference. Reflecting the reformist approach of the Campaign against Climate Change, the march was planned to end outside Parliament: “...the reason for going to parliament is fundamental because we're attempting to address power... Some people would disagree and try to change government, but we are trying to influence government without necessarily saying that we like them.” (Phil, interview, February 2012). In this way, the Campaign against Climate Change could be seen as aiming to challenge the prevailing system of thought by attempting to "converting practical consciousness into discursive consciousness" (Haugaard 2003: 100). Insofar as parliamentary political actors respond with inadequate solutions grounded in economic 
growth, it may be a failed attempt, which instead results in structural reproduction (Haugaard 2003).

\section{Reformist outsiders and media visibility}

The Climate Justice march was mainly driven by a logic of numbers, which served the purpose of gaining media attention. For the Campaign against Climate Change, the role of mass media coverage in generating sympathy for a cause among broader publics is key. Without visibility in the mass media the march was unlikely to reach beyond the confines of the activist community (Cammaerts 2012; Gitlin 1998). It relied on the increased news value afforded climate change by the UN Climate Conference. The march took place on a Saturday and apart from tourist visitors and a heavy police presence, the Westminster area was virtually empty. The main organizer of the demonstration encouraged demonstrators to shout loud enough for the people inside Westminster to hear them, adding "well, if they were actually in there today." The 2011 Climate Justice march was clearly not planned to reach MPs unmediated. As he later explained: "It has to be a Saturday to get enough people to turn up, and then it's about the media-for the media getting a picture in front of the House of Commons, it's simple." (Phil, interview, February 2012). In Arendt's terms, this illustrates an attempt to act in concert and to do so in the space of appearance.

\section{Anti-systemic climate justice activism}

At COP15 in 2009, the activist group Never Trust a Cop provides an apt example of an anti-systemic extra-parliamentarian actor that chose to remain outside the UN Climate Conference to voice their critique. Never Trust a COP dissolved shortly after the climate conference, thus illustrating the often provisional and single-issue nature of 
contemporary extra-parliamentarian political groups. The group came into being in the run-up to the climate demonstrations at COP15. It was formed at a meeting in the social centre, the Youth House, in the aftermath of a much larger mobilization meeting held by a wide range of actors involved in the organization of COP15 demonstrations, including well-established reformist NGO such as Friends of the Earth and Climate Justice Action. Here, Never Trust a COP was formed as a response to reformist and less radical tactics proposed at the meeting. To Never Trust a COP reformist or civil disobedience tactics would not sufficiently condemn the summit as a forum for profitdriven responses to climate change. Instead, Never Trust a COP called for a conflictual approach, with street riots and confrontational demonstrations. In this sense, Never Trust a COP can be understood as dissenters of this more formal mobilization meeting and as what was to become a rally ground for activists keen to break with the agendas and strategies of more consensus-oriented or reformist factions. In other words, they chose a position of "ideological outsiders" (Binderkrantz 2008) to point to the UNFCCC as an illegitimate system that they do not want to risk reifying. However, they were simultaneously excluded from reformist activist networks, and had they attempted to obtain formal access approval to the conference, they would most certainly have failed (Author 2013). In this way, anti-systemic actors were excluded from a particular public sphere, illustrating unequal power relations created by system bias (Haugaard 2003). In this way, Never Trust a COP had no access to policy makers and were positioned at the radical end of the agenda axis.

\section{Ideological outsiders and social media visibility}

The interplay between Never Trust a COP's lack of access and radical agenda had consequences for their possibilities for achieving visibility for their cause. Social media 
played a key role in giving visibility to Never Trust a COP. As part of their campaign, the group uploaded a mobilization video to YouTube calling for activists to come to Copenhagen "to show a dead system how to die." (Author 2013). The video shows masked activists wielding bricks and gas canisters. Molotov cocktails, black balaclavas and scarves and overturned police vehicles feature as iconographic signs of protest that feed into a counter-discourse in which the power of visual imagery is used to mobilize and sustain dissent. Explicitly stating an affiliation with Never Trust a COP, YouTube user Civilspan uploaded the video in October 2009. The video received approximately 25,000 views in 2009 . While this is generally a relatively modest number, as a mobilisation video aiming to reach likeminded activists, it was a high number (Author 2011). But the video also generated mass media attention. On 22 November, some two weeks before the COP15 summit, it made the six o'clock news and attracted headlines in almost every Danish newspaper. The Never Trust a COP network was labelled criminal vandals and became the centre of attention in the mass media (Author 2011). While many climate activists struggled to get air time, Never Trust a COP achieved the media spotlight unwillingly, and chose not to speak to the press before, during or after the summit. Several journalists made unsuccessful attempts to get interviews, and Never Trust a COP's silence gave free vent to interpretation and condemnation, without anyone contradicting these perspectives on the story. The negative media coverage, portraying activists as thugs looking for trouble rather than citizens expressing their frustration with a political cause and/or system illustrates a wider tendency (Feigenbaum et al. 2012). A significant implication is that social media do not merely enable extra-parliamentarian political actors to communicate in a way "that bypasses mass media and often escapes government control" (Castells 2008, p. 90). Rather they rely on mass media coverage to reach beyond so-called echochambers of likeminded 
users, and they operate by similar logics which privilege the spectacular in terms of visibility. In terms of government control, the case of Never Trust a COP illustrates the possibilities for surveillance that social media enable. Following the circulation of the War on Capitalism video on YouTube, the Danish police announced that they were initiating an investigation into the activists behind the video (Author 2011). Climate

justice activists faced severe police repression, including unlawful mass arrests, having their houses searched and being pepper-sprayed while held in cages (Chatterton et al. 2013). The severely repressive policing and juridical structures that face activists impede possibilities for expressing political contention through coercive power, also in social media. Experiences of coercive power have made activists cautious in their communicative practices. Acutely aware that the police monitor social media, activists see these as appropriate only for the dissemination of non-sensitive information. In this way, coercive power on the streets creates disciplinary power in social media platforms. The Danish authorities' intensive search for Never Trust a COP members, and the extreme monitoring of climate justice activists in general, impedes their possibilities for openly organizing and debating acts of political contestation. The visibility afforded by social media operates asymmetrically, enabling governments and corporations to monitor citizens' activities without being seen themselves (Fuchs et al. 2013). In this way, social media augment visibility asymmetries by rendering them less transparent and accountable (Brighenti 2010). This contribution to visibility asymmetries is underpinned by the business models of social media platforms.

\section{Visibility and the business of digital media platforms}

Commercial social media platforms such as YouTube rely on boosting revenue generation and access to new markets, which requires avoiding negative publicity and 
appealing to advertisers and a wide range of non-activist users (Youmans and York 2012). This often translates into terms of service that complicate activist uses of the platforms by requiring users to provide their real names and address and by passing this information on to government authorities without hesitation (Hestres 2013; Juris, 2013; Papacharissi and Fernback 2005). In this way, many activists are unable to keep their identities invisible and actions visible when using Youtube. In contrast, non-profit platforms that rely on open source technologies and volunteer support are more willing to resist corporate requests to remove critical content and government requests for user data (Author 2017). In this way, not-profit platforms are more willing to counter panoptic power and power created by coercion. But as commercial platforms such as Youtube and Facebook have become the go-to platforms for many activists and, not least, the publics they aim to reach, risks of exposure and censure are difficult to avoid (Author 2018). These interrelations between the governance and architecture of Internet technologies on the one hand and visibility asymmetries on the other render invisible several aspects of the logics and mechanisms that drive social media practices. Invisibility contributes to a naturalization of these logics and the hegemony of the market. This illustrates some of the ways in which social media are embedded in wider power structures and the implications this has for extra-parliamentarian political communication. It also gestures towards a more general datafication of visibility which is driven by the commercial interests of corporate tech giants such as Facebook and Google, what Zuboff (2015) has termed 'surveillance capitalism' (p. 75). In this trajectory, visibility asymmetries in social media platforms are augmented, impeding possibilities for compensating for lack of access to government and policy makers through social media visibility. 


\section{Concluding remarks: The significance of context}

In assessing the role of the interplay between extra-parliamentarian political actors' political agenda and access to policy makers, key questions for future research should pay attention to context. This is no less important in relation to social media. Not only do different political actors have different degrees of visibility in the media, so do different policy areas (Nielsen, 2015). For example, social media platforms may have played a prominent role in protests against the Stop Online Privacy Act (SOPA) and the Anti-Counterfeiting Trade Agreement (ACTA), but it does not follow that they have been important for lobbying on economic policy or security policy (Nielsen 2015). Arguing for the significance of paying attention to context, Nielsen (2015) points to Campbell and Pedersen's (2014) work on policy knowledge regimes to capture differences in the organizational and institutional machineries that generate data, research, policy recommendations that influence elite debates and policymaking. From this perspective, they identify different knowledge regimes and argue that visibility and external strategic communication is key to extra-parliamentarian political actors' possibilities for influencing policymakers in some national contexts, while backstage lobbying and corporatist resources is key in other contexts. In relation to the transnational case of the UNFCCC meetings, this reminds us to pay attention to not only the particularities of the climate policy arena, but also national contexts. These are significant in two ways. One relates to the national context of the host nation and the other to the national contexts of participating countries. In the case of the UN climate conferences, these can be seen as mediation opportunity structures for a wide range of extra-parliamentarian political actors to bring attention to their various climate agendas (Author 2013). However, the structural power inequalities of the summits - both in terms of summit procedures and participant resources - mean that being allowed to 
participate in negotiations does not mean that all participants have similar possibilities for making their voices heard (Banerjee 2012). Adding to this, NGO delegates include BINGOs (Business and Industry NGOs). The major multi-national oil corporations such as Shell, BP and ExxonMobil, nuclear corporations such as Areva as well as mining corporations such as Rio Tinto and BHP Billiton have all funded NGOs that have significant resources (Banerjee 2012). Also industry associations such as the International Council on Mining and Metals and the World Business Council for Sustainable Development have privileged positions for participating in negotiations (Banerjee 2012). This illustrates some of the ways in which the corporation plays an increasingly important role as an extra-parliamentarian actor in sustainability issues (Author 2015). In contrast, NGOs with fewer resources and non-commercial agendas are more likely to be excluded and thus rely on (social) media visibility with the advantages and disadvantages that entails. For many activists, visibility at the UN climate conferences entails immediate disadvantages on a personal level that can come to outweigh the advantages of visibility. At COP17 in Durban, dozens of protestors, mainly environmental activists from NGOs such as Greenpeace and Friends of the Earth were deported during the first week of the conference (Banerjee 2012). In the case of the COP15 climate summit in Copenhagen, severe pre-emptive policing introduced just before the summit resulted in mass arrests (Author 2013). Such measures of disciplinary power make activists wary of coming forward to explain their protests to the press or in social media, thus impeding possibilities for visibility and for challenging the logics of economic growth that underpin mainstream responses to current societal crises such as the climate crisis.

This article has focused on the context of the UNFCCC meetings and extraparliamentarian political participation at the progressive left at a time when the role of 
the business models of commercial social media platforms was relatively new and under-examined. More recent developments gesture towards increasing fragmentation and spreading of mis-information. In relation to the UNFCCC meetings and the climate crisis, right-wing extra-parliamentarian actors are increasingly visible in digital media, often attacking climate crisis discourse as intellectualism and subjective opinion (Dahlgren 2018; Lockwood 2018). Right-wing discourses, including climate change denial, seem to be on a powerful course towards normalization and access to parliament (Bennett and Pfetsch 2018; Cammaerts 2018). In this context, key questions for future research include how the interplay between access to parliament and political agendas influence hegemonic struggles and connections between discourses of democracy and societal change (De Cleen and Stavrakakis 2017; De Cleen 2018). 


\section{References}

Allan, J. I., and Hadden, J., 2017. Exploring the framing power of NGOs in global climate politics. Environmental Politics, 26(4), 600-620.

Allen, A., 1998. Rethinking power. Hypatia, 13(1), 21-40.

Almond, G. A. and Verba, S., 1963. The Civic Culture: Political Attitudes and Democracy in Five Nations. London: Sage.

Ahrne, G., Brunsson, N., \& Seidl, D., 2016. Resurrecting organization by going beyond organizations. European Management Journal, 34(2), 93-101.

Bailey, D. J., and Bates, S. R., 2012. Struggle (or its absence) during the crisis: what power is left?. Journal of Political Power, 5(2), 195-216.

Banerjee, S. B., 2011. Embedding sustainability across the organization: A critical perspective. Academy of Management Learning \& Education, 10(4), 719-731.

Banerjee, S. B., 2012. A climate for change? Critical reflections on the Durban United Nations climate change conference. Organization Studies, 33(12), 1761-1786.

Baron, D. P., 2003. Private politics. Journal of Economics \& Management Strategy, 12(1), 31-66. 
Bennett, W., 2003. Communicating global activism. Information, Communication \& Society, 6(2), 143-168.

Bennett, W. L., 2012. The personalization of politics political identity, social media, and changing patterns of participation. The Annals of the American Academy of Political and Social Science, 644(1), 20-39.

Bennett, W. L., Wells, C., and Freelon, D., 2011. Communicating civic engagement: Contrasting models of citizenship in the youth web sphere. Journal of Communication, 61(5), 835-856.

Bennett, W. L., and Segerberg, A., 2013. The Logic of Connective Action: Digital Media and the Personalization of Contentious Politics. Cambridge: Cambridge University Press.

Bennett, W. L., Segerberg, A., and Walker, S., 2014. Organization in the crowd: Peer production in large-scale networked protests. Information, Communication \& Society, $17(2), 232-260$.

Bennett, W.L. and Pfetsch, B., 2018. Rethinking Political Communication in a Time of Disrupted Public Spheres, Journal of Communication, 68(2): 243-253

Binderkrantz, A., 2008. Different groups, different strategies: How interest groups pursue their political ambitions. Scandinavian Political Studies, 31(2), 173-200. 
Blach-Ørsten, M., \& Kristensen, N. N., 2016. Introduktion: Tænketanke i de nordiske lande. Politik, 19(1).

Bloom, P. (2013). The power of safe resistance. Journal of Political Power, 6(2), 219239.

Binderkrantz, A. S., 2015. Balancing gains and hazards: Interest groups in electoral politics. Interest Groups \& Advocacy, 4(2), 120-140.

Boltanski, L., \& Chiapello, E., 2005. The new spirit of capitalism. International journal of politics, culture, and society, 18(3-4), 161-188.

Böhm, S., Spicer, A., and Fleming, P., 2008. Infra-political dimensions of resistance to international business: A Neo-Gramscian approach. Scandinavian Journal of Management, 24(3), 169-182.

Brundidge, J., 2010. Encountering 'difference' in the contemporary public sphere: The contribution of the Internet to the heterogeneity of political discussion networks. Journal of Communication, 60(4), 680-700.

Calhoun, C. J., 1992. Habermas and the public sphere. Cambridge, MA: MIT press.

Cammaerts, B., 2018. The Circulation of Anti-Austerity Protest. Basingstoke: Palgrave-MacMillan. 
Cammaerts, B., 2012. Protest logics and the mediation opportunity

structure. European journal of communication, 27(2), 117-134.

Cammaerts, B., 2007. Jamming the political: Beyond counter-hegemonic practices. Continuum, 21(1), 71-90.

Carpentier, N., 2012. Discursive Structures in the Network Society. Javnost-The Public, 19(4), 25-40.

Castells, M., 2013. Networks of Outrage and Hope: Social Movements in the Internet Age. Malden, MA: Polity Press

Chatterton, P., Featherstone, D., and Routledge, P., 2013. Articulating climate justice in Copenhagen: antagonism, the commons, and solidarity. Antipode, 45(3), 602-620.

Couldry, N., Livingstone, S. M., and Markham, T., 2007. Media Consumption and Public Engagement: Beyond the Presumption of Attention. Basingstoke: Palgrave Macmillan.

Dahlberg, L., 2001. The Internet and democratic discourse: Exploring the prospects of online deliberative forums extending the public sphere. Information, Communication \& Society, 4(4), 615-633.

Dahlberg, L., 2014. The Habermasian public sphere and exclusion: An engagement with poststructuralist-influenced critics. Communication Theory, 24(1), 21-41. 
Dahlgren, P., 1995. Television and the Public Sphere: Citizenship, Democracy and the Media. London: Sage.

Dahlgren, P., 2001. 'The Public Sphere and the Net: Structure, Space and Communication', In L.W. Bennett and R.M. Entman (eds) Mediated Politics:

Communication in the Future of Democracy, pp. 33-55. Cambridge: Cambridge University Press.

Dahlgren, P., 2003. "Reconfiguring Civic Culture in the New Media Milieu." In J. Corner, and D. Pels, Media and the Restyling of Politics, London: Sage, 150-170.

Dahlgren, P., 2005. The Internet, public spheres, and political communication: Dispersion and deliberation. Political communication, 22(2), 147-162.

Dahlgren, P., 2009. Media and Political Engagement. Cambridge: Cambridge University Press.

Dahlgren, P., 2013. The Political Web: Participation, Media, and Alternative Democracy. Basingstoke: Palgrave Macmillan.

Dahlgren, P., 2018. Media, Knowledge and Trust: The Deepening Epistemic Crisis of Democracy, Javnost - The Public, 25:1-2, 20-27

Dean, M., 2012. The signature of power. Journal of Political Power, 5(1), 101-117. 
De Bakker, F. G., den Hond, F., King, B., and Weber, K., 2013. Social movements, civil society and corporations: Taking stock and looking ahead. Organization Studies, 34(5-6), 573-593.

De Bakker F.G.A., 2015. Online Activism, CSR and Institutional Change. In: Uldam J., Vestergaard A. (eds) Civic Engagement and Social Media. London. Palgrave Macmillan.

De Cleen, B., 2018. The conservative political logic: a discourse-theoretical perspective. Journal of Political Ideologies, 23(1), 10-29.

De Cleen, B., \& Stavrakakis, Y., 2017. Distinctions and articulations: A discourse theoretical framework for the study of populism and nationalism. Javnost-The Public, 24(4), 301-319.

Dencik, L., Hintz, A., \& Cable, J., 2016. Towards data justice? The ambiguity of antisurveillance resistance in political activism. Big Data \& Society, 3(2), 2053951716679678.

Den Hond, F., and De Bakker, F. G., 2007. Ideologically motivated activism: How activist groups influence corporate social change activities. Academy of Management Review, 32(3), 901-924. 
Della Porta, D., and Tarrow, S., 2005. Transnational processes and social activism: An introduction. Transnational protest and global activism, 1 .

Feigenbaum, A., Frenzel, F., and McCurdy, P., 2013. Protest Camps. London: Zed Books.

Fenton, N., 2008. Mediating hope: New media, politics and resistance. International Journal of Cultural Studies, 11(2), 230-248.

Fenton, N., and Barassi, V., 2011. Alternative media and social networking sites: The politics of individuation and political participation. The Communication Review, $14(3), 179-196$.

Gilbert, D. U., and Rasche, A., 2007. Discourse ethics and social accountability: The ethics of SA 8000. Business Ethics Quarterly, 187-216.

Gitlin, T., 1998. Public sphere or public sphericules? In: T. Liebes, \& J. Curran (eds), Media Ritual and Identity (pp. 168-174). London: Routledge.

Greenwood, R., Suddaby, R., and Hinings, C. R., 2002. Theorizing change: The role of professional associations in the transformation of institutionalized fields. Academy of Management Journal, 45(1), 58-80. 
Habermas, J., 2006. Political communication in media society: Does democracy still enjoy an epistemic dimension? The impact of normative theory on empirical research. Communication Theory, 16(4), 411-426.

Hintz, A., 2014. Outsourcing Surveillance-Privatising Policy: Communications Regulation by Commercial Intermediaries. Birkbeck L. Rev., 2, 349.

Holz, C., 2012. The public spheres of climate change advocacy networks: an ethnography of Climate Action Network International within the United Nations Framework Convention on Climate Change (UNFCCC) (Doctoral dissertation, University of Glasgow).

Iosifidis, P., 2011. The public sphere, social networks and public service media. Information, Communication \& Society, 14(5), 619-637.

Juris, J. S., 2012. Reflections on \#Occupy Everywhere: Social media, public space, and emerging logics of aggregation. American Ethnologist, 39(2), 259-279.

Kavada, A., 2013. Internet cultures and protest movements: the cultural links between strategy, organizing and online communication. In: Cammaerts, B., Mattoni, A. and McCurdy, P. (ed.) Mediation and protest movements. London Intellect. pp. 75-94

Landwehr, M., Borning, A. and Wulf, V., 2019. The High Cost of Free Services: Problems with Surveillance Capitalism for IT Infrastructure and Possible Alternatives. 
In Proceedings of Fifth Workshop on Computing within Limits (LIMITS 2019). ACM, New York, NY, USA, Article 4, https://doi.org/10.475/123_4

Karagianni, K. S., and Cornelissen, J., 2006. Anti-corporate movements and public relations. Public Relations Review, 32(2), 168-170.

King, B. G., and Pearce, N. A., 2010. The contentiousness of markets: Politics, social movements, and institutional change in markets. Annual review of sociology, 36, 249267.

Lockwood, M., 2018. Right-wing populism and the climate change agenda: exploring the linkages, Environmental Politics, 27:4

Nielsen, RK., 2015. Social media and policy processes - three comparative perspectives, Paper for "Social media and the prospects for expanded democratic participation in national policy-setting", Workshop at Boston University, April 9 2015.

Kraemer, R., Whiteman G., and Banerjee, B., 2013. Conflict and astroturfing in Niyamgiri: The importance of national advocacy networks in anti-corporate social movements, Organization Studies, 34, 823.

Lechaux, B., 2010. Non-preaching activism in New York. The theatrical militancy of billionaires for Bush and reverend Billy. International Journal of Politics, Culture, and Society, 23(2-3), 175-190. 
Lilja, M., and Vinthagen, S., 2018. Dispersed resistance: unpacking the spectrum and properties of glaring and everyday resistance. Journal of Political Power, 1-19.

Lilja, M., Baaz, M., Schulz, M., and Vinthagen, S., 2017. How resistance encourages resistance: theorizing the nexus between power, 'Organised Resistance'and 'Everyday Resistance'. Journal of Political Power, 10(1), 40-54.

Lukes, S., 2005. Power: a Radical View $-2^{\text {nd }}$ Edition. Basingstoke: Palgrave Macmillan.

Lunt, P., and Livingstone, S., 2013. Media studies' fascination with the concept of the public sphere: Critical reflections and emerging debates. Media, Culture \& Society, 35(1), 87-96.

Mansell, R., 2010. Commentary - mediating the public sphere: Democratic deliberation, communication gaps, and the personalization of politics. In Charles T. Salmon (ed.) Communication Yearbook 34 (pp. 259-274). Oxford: Routledge.

Mouffe, C., 2005. The return of the political. London: Verso.

Matten, D., and Crane, A., 2005. Corporate citizenship: Toward an extended theoretical conceptualization. Academy of Management review, 30(1), 166-179.

Munro, W. A., Schurman, R. A., Wright, W., and Middendorf, G., 2008. Sustaining outrage: Cultural capital, strategic location, and motivating sensibilities in the US 
anti-genetic engineering movement. In: Wright, W. and Middendorf, G. (eds) The Fight over Food: Producers, Consumers, and Activists Challenge the Global Food System, University Park, PA: Penn State University Press.

Neumayer, C., \& Svensson, J., 2016. Activism and radical politics in the digital age: Towards a typology. Convergence, 22(2), 131-146.

Palazzo, G., and Scherer, A. G., 2008. Corporate social responsibility, democracy, and the politicization of the corporation. Academy of Management Review, 33(3), $773-775$.

Papacharissi, Z., and Fernback, J., 2005. Online privacy and consumer protection: An analysis of portal privacy statements. Journal of Broadcasting \& Electronic Media, 49(3), 259-281.

Papacharissi, Z., 2004. Democracy online: Civility, politeness, and the democratic potential of online political discussion groups. New Media \& Society, 6(2), 259-283.

Reitan, R., and Gibson, S., 2012. Climate change or social change? Environmental and leftist praxis and participatory action research. Globalizations, 9(3), 395-410.

Richey, L. A., \& Ponte, S. (2011). Brand aid: Shopping well to save the world. Minnesota: Uiversity of Minnesota Press. 
Scherer, A. G., and Palazzo, G., 2011. The new political role of business in a globalized world: A review of a new perspective on CSR and its implications for the firm, governance, and democracy. Journal of Management Studies, 48(4), 899-931.

Schoeneborn, D., \& Scherer, A. G., 2012. Clandestine organizations, al Qaeda, and the paradox of (in) visibility: A response to Stohl and Stohl. Organization Studies, 33(7), 963-971.

Soneryd, L., and Wettergren, Å., 2017. How Does Climate Change Transnationalise Environmental Movement Organisations? The Case of Denmark. Global Society, 31(1), 23-42.

Tarrow, S., 2001. Transnational politics: Contention and institutions in international politics. Annual Review of Political Science, 4(1), 1-20.

Van Laer, J., and Van Aelst, P., 2010. Internet and social movement action repertoires: Opportunities and limitations. Information, Communication \& Society, 13(8), 1146-1171.

Van Zoonen, L., Vis, F., and Mihelj, S., 2010. Performing citizenship on YouTube: Activism, satire and online debate around the anti-Islam video Fitna. Critical Discourse Studies, 7(4), 249-262.

Whelan, G., 2013. The political perspective of corporate social responsibility: A critical research agenda. Business Ethics Quarterly, 22(4), 709-737. 
Youmans, W. L., and York, J. C., 2012. Social media and the activist toolkit: User agreements, corporate interests, and the information infrastructure of modern social movements. Journal of Communication, 62(2), 315-329. 
Figure 1: Typological axes of extra-parliamentarian political power

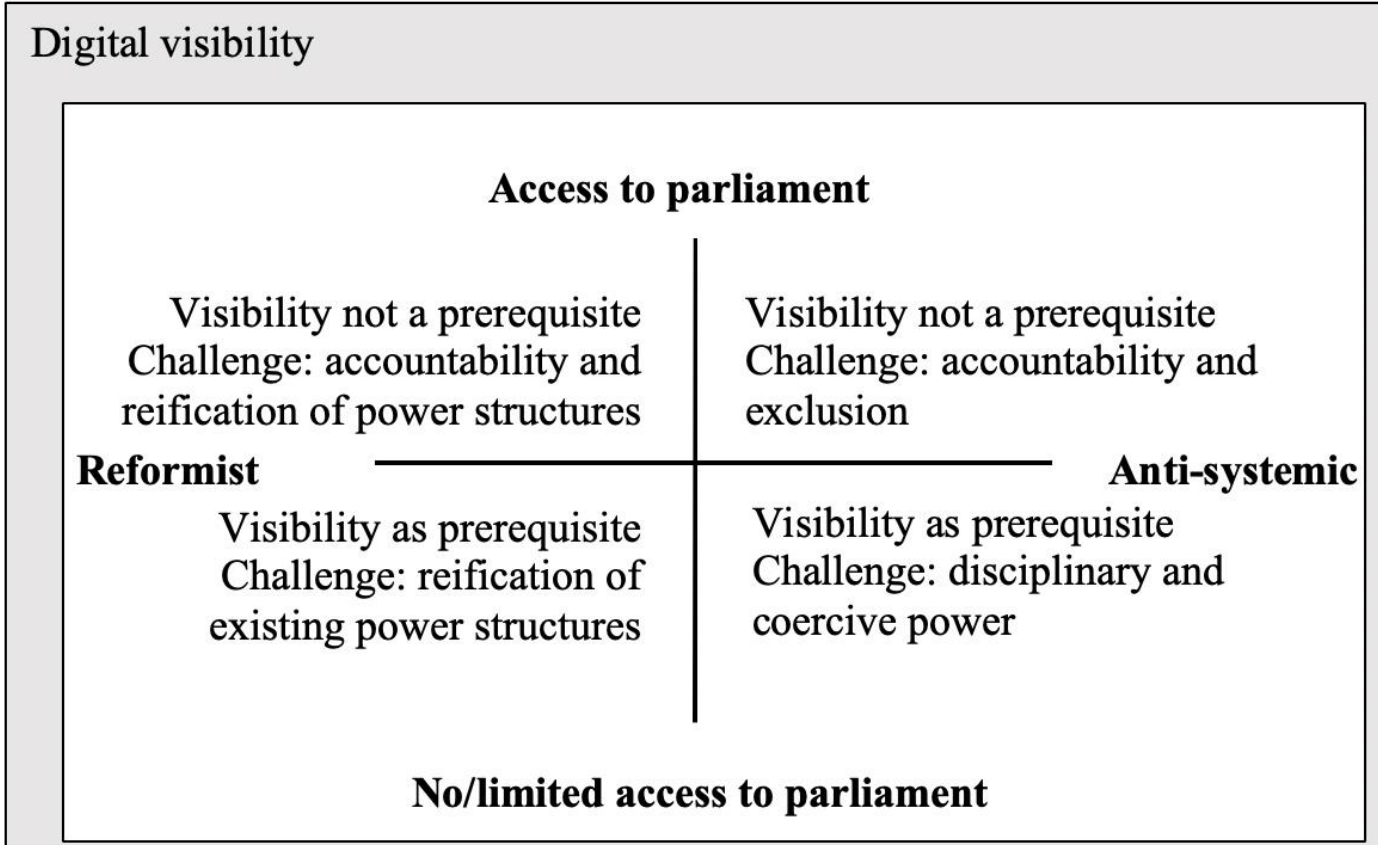

